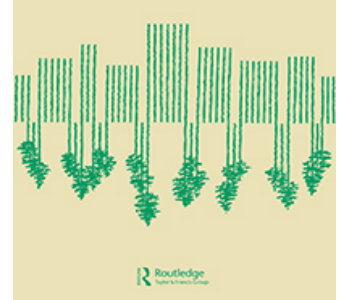

\author{
An International journal
}

\title{
The Gender Gap in Water Management Preferences: Analyzing the Influence of Environmental Concern and Political Knowledge
}

\section{Regina Lafuente, Pilar Paneque \& Jose Luis Cañadas}

To cite this article: Regina Lafuente, Pilar Paneque \& Jose Luis Cañadas (2021) The Gender Gap in Water Management Preferences: Analyzing the Influence of Environmental Concern and Political Knowledge, Society \& Natural Resources, 34:11, 1472-1491, DOI: 10.1080/08941920.2021.1971808

To link to this article: https://doi.org/10.1080/08941920.2021.1971808

\section{Published online: 06 Sep 2021.}

\section{Submit your article to this journal $₫$}

山 Article views: 301

View related articles

View Crossmark data $₫$ 


\title{
The Gender Gap in Water Management Preferences: Analyzing the Influence of Environmental Concern and Political Knowledge
}

\author{
Regina Lafuente $^{\mathrm{a}}$ (D) Pilar Paneque $^{\mathrm{b}}$ (D) and Jose Luis Cañadas ${ }^{c}$ \\ anstitute for Advanced Social Studies, Spanish National Research Council, Cordova, Spain; ${ }^{b}$ Department \\ of Geography, History and Philosophy, University Pablo de Olavide, Seville, Spain; ${ }^{\text {R R-Hispano }}$ \\ Community, Madrid, Spain
}

\begin{abstract}
To date, most studies on the role of women in water management have focused on local communities in developing countries, within which women are more vulnerable to hydrological risk. This study emphasizes the need to investigate the preferences of women in industrialized nations. The results of a representative opinion survey in Andalusia (Spain) reveal that, when it comes to water management, women tend to think primarily in domestic terms whereas men prioritize the efficiency of irrigation systems. In Andalusia (a region under severe risk of hydrological stress) irrigation has a much greater impact on the efficiency of water use than any other factor. To explain these differences of opinion, this study analyses the gender gap in terms of environmental concern and political knowledge. The results suggest that women's preferences relate not only to their greater environmental proactiveness in the domestic sphere but also to political-knowledge-related variables.
\end{abstract}

\section{ARTICLE HISTORY}

Received 1 November 2020 Accepted 28 July 2021

\section{KEYWORDS}

Environmental concern; gender gap; political knowledge; Spain; water management

\section{Introduction}

Improving water management is at the top of the political agenda worldwide. According to the guidelines put forward by OECD (2015a), water governance comprises the range of political, institutional and administrative rules, practices and processes (formal and informal) through which decisions are taken and implemented, stakeholders can articulate their interests and their concerns, and decision-makers are held accountable for water management. Understanding, designing and implementing water policies so that the interests of all stakeholders, including the citizen body, are addressed and long-term sustainability targets are met is a major challenge (OECD 2015b, 2018). Although the effectiveness of existing participation processes concerning water management have been assessed (Akhmouch and Clavreul 2016), different international organizations warn that the analysis of water management must not only take into

CONTACT Regina Lafuente $\otimes$ rlafuente@iesa.csic.es $\theta$ Institute for Advanced Social Studies, Spanish National Research Council, Cordova, Spain.

(4) Supplemental data for this article can be accessed on the publisher's website https://doi.org/10.1080/08941920. 2021.1971808 
consideration local communities but also specifically analyze the roles of women (IUCN 2018).

These reports demand that more attention be paid to women as users of water in both domestic and productive contexts, thereby encouraging their participation in decision-making processes. Stereotypes and cultural norms in developing regions often prevent women from accessing formal institutions, and it is argued that promoting informal institutions may act as a steppingstone for their progressive incorporation into the process of water governance (IUCN 2018). Some studies warn that incorporating women into formal water-management structures from a strictly technocratic perspective and without taking into consideration their role in local communities has sometimes hampered women empowerment and hindered changes in water management (Cleaver 1998; Cleaver and Hamada 2010; Van Houweling 2016).

Most studies about the role of women in water management have focused on local communities in developing countries, and several factors converge to obscure the issue in industrialized countries. First, international organizations are largely concerned with the north-south divide, and issues such as accessible and clean water in developing countries, in which women are more vulnerable to hydrological risks, have taken center stage (UNESCO 2015; World Bank (WB)) 2019). Second, gender categories have generally been used to describe power relations, which has resulted in a theoretical body linked to activism and social change (Arora-Jonsson 2014). Third, it is often assumed that, in industrialized countries, institutions and organizations are gender equal, and therefore this is not a relevant category from a political point of view (Calás et al. 2014).

However, recent years have witnessed an increasing concern for gender issues in relation to environmental policies in Europe, and environment ministries are developing plans for incorporating the gender perspective into their policies (Arora-Jonsson 2014). This growing interest in gender issues is not only visible at the political level: more and more academic studies are trying to examine climate change adaptation plans in industrialized countries from a gender perspective (Arora-Jonsson 2011; MacGregor 2009; Nagel 2015; Pearse 2017). However, the number of studies that analyze water governance in industrialized countries from a gender perspective remains small (ig, Figueiredo and Perkins 2013), despite the obvious connection to climate change adaptation (EEA 2017; IPCC 2014).

The increasing frequency and intensity of drought episodes caused by climate change pose a challenge to water management in a growing number of regions: countries such as Spain are under severe threat of hydrological stress (Centro de Estudios y Experimentación de Obras Públicas (CEDEX)) 2017a; Sánchez-Plaza, Broekman, and Paneque 2019). This is the case of Andalusia, a region in southern Spain, is $87,597 \mathrm{~km}^{2}$ in size (17.3\% of Spain's area) and $8,414,240$ inhabitants (17.9\% of national population). Its population is defined by a greater demographic dynamism than that of the rest of the country, which is reflected both in a less aged population structure (those under 18 years of age account for $18.9 \%$ of the population of Andalusia, compared to $13.2 \%$ of the national average) and by a larger average household size (2.6 compared to 2.3) (Instituto de Estadística y Cartografía de Andalucía (IECA) 2020). It is in relation to the labor market where Andalusia presents more negative data compared to the national 
ones, since the region doubles the unemployment rate $(23.8 \%$ on average and up to $28.5 \%$ in the case of women) and the active population dedicated to agriculture $(9.3 \%$, being the dedication of men three times higher than that of women) (Instituto de Estadística y Cartografía de Andalucía (IECA) 2020). These differences derive from territorial and economic processes sustained over time that have led to significant inequalities between the south and north of Spain (Tirado, Díez-Minguela, and MartínezGalarraga 2016), which can be summarized in the average personal income figure: $€ 8,400$ in Andalusia and more than $€ 12,000$ in regions of northern Spain, such as Catalonia (Instituto Nacional de Estadística (INE) 2020).

Regarding water resources, it is important to point out that annual precipitation is $643.5 \mathrm{~mm}$ (series 1981-2010), although rainfall is unevenly distributed by season, leading to an alternation of dry and humid cycles. During the latest drought episodes (1941-1945, 1979-1983, 1990-1995, 2005-2008), precipitation fell by between 23 and $30 \%$. Climate change will increase the frequency and severity of drought episodes, and predictions suggest that this effect will be especially severe in southern Spain (EEA 2017; IPCC 2014). In recent years, drought management in Spain has moved toward prevention (Paneque 2015), but not enough attention is being paid to climate change as a factor in hydrological planning (Sánchez-Plaza, Broekman, and Paneque 2019); specifically, water planning in Andalusia forecasts a decrease of only $8 \%$ of available water resources by 2033. Recent works forecast that the decrease will be greater leading to difficulties in meeting demands (Centro de Estudios y Experimentación de Obras Públicas (CEDEX) 2017a). Currently, according to the Andalusian River Basin Districts Plans (2016-2021) the water-stress level is among the highest in Europe, and this has an effect on the deficient condition of water bodies (Centro de Estudios y Experimentación de Obras Públicas (CEDEX) 2017b). As a result of all these factors, the region is very vulnerable to drought.

This situation of reduction and overexploitation of water resources, which is clearly manifested in Water Exploitation Index values above $40 \%$, has been accompanied by a strategy shift in water planning. Thus, since the publication of the Water Framework Directive (WFD) in 2000, water-management strategies have been shifting in Andalusia from a supply-management to a demand-management approach. One of the main aims of this shift is to promote more efficient uses of water (Del Moral et al. 2003). Over the past two decades, the regional government has funded irrigation improvement plans, but the Andalusian River Basin Districts Plans (2016-2021) continue to prioritize agricultural consumption ( $82 \%$ of total consumption), compared to $15 \%$ household consumption and 3\% industrial consumption (Sampedro and del Moral 2014). The water demand for agricultural uses has grown constantly in Andalusia and even more so since the end of the 1990s, which is directly related to the linkage of European Union aid to agricultural production and, derived from this, to the fact that many traditionally dryland crops have been transformed into irrigated crops (Sampedro and del Moral 2014). This is the case of the olive crop-Andalusia's main crop (60\% of the total), which extends over 1.5 million hectares, accounting for $37 \%$ of world production and $50 \%$ of European production-whose irrigated cultivation has increased in the last ten years from 25 to 38\% (Ministerio de Agricultura, Pesca y Alimentación (MAPAMA) 2020). The expansion of irrigation has required significant investment in hydraulic 
infrastructures, which is well exemplified by the existence of 66 major reservoirs with an aggregate capacity of $8,283.5 \mathrm{Hm}^{3}$ (Ministerio para la Transición Ecológica y el Reto Demográfico (MITECO) 2020), which seek to meet agricultural demands. On the one hand, this reality is a clear representation of the power that this sector has traditionally had throughout the country (Swyngedouw 2015). In contrast, household consumption has shrunk all over Spain and also in Andalusia, especially in the aftermath of the major 1992-1995 drought, from 200 to 125 liters/person/day. Although the overall effect of this decrease is dwarfed by agricultural consumption, it reflects operational changes that have resulted in greater efficiency in water transport and distribution and changes in pricing systems, but also profound changes in public perceptions, values and habits (Sampedro and del Moral 2014; Villarín 2019).

This paper focuses on analyzing the preferences of the Andalusian population regarding these two main demand management strategies, improving irrigation efficiency and reducing domestic consumption. Previous studies have already noted that, in Andalusia, there is a greater tendency among men to support irrigation efficiency, while women give more importance to domestic saving (Lafuente and Moyano 2011). Since $84 \%$ of the water consumed in Andalusia goes to agricultural uses, men preferences have a greater impact in terms of efficiency.

The debate concerning the incorporation of women into water-management processes in developing countries emphasizes the need to examine other related issues as gender differences concerning water-management preferences in industrialized contexts, especially in areas such as Andalusia with a significant water stress problem. To this aim, gender research provides concepts to describe society and the differences in opinions between men and women around the world. This study examines the issue with regard to two areas of study in which empirically informed gender studies are especially advanced in industrialized countries and that can offer valuable insight into these gender-sensitive differences in the support of different water management measures: environmental concern and political knowledge.

\section{Literature Review: Women, Environmental Concern and Political Knowledge}

The most common responses to the gender gap are based on the "gender socialisation theory", which establishes that in the socialization process, a number of roles are attributed to men and women that explain gender differences in adulthood (Chafetz 2006; Gilligan 1982). In general, it is argued that men are socialized to assume greater public responsibility whereas women are socialized to focus on the domestic and private spheres. These differences put women at a disadvantage in multiple spheres, such as access to the job market, education and domestic work. The following sections examine arguments used to explain differences in environmental concern and political knowledge based on gender.

\section{Gender Gap in Environmental Concern}

Environmental concern denotes the degree of individual concern for environmental problems and individual willingness to personally contribute to their solution (Dunlap 
and Jones 2002). It is a multidimensional concept divided into two main dimensions: environmental beliefs and specific environmental issues.

A number of empirical studies (Dzialo 2017; Kennedy and Kmec 2018; McCright and Xiao 2014; Strapko et al. 2016; Zelezny, Chua, and Aldrich 2000) suggest that women are more environmentally aware than men in industrialized countries. This environmental concern is especially acute when it comes to issues, which pose a risk to the health of their families and communities. Women also are more prone to adopt pro-environmental private habits, such as recycling or water saving. There are, in contrast, no major gender differences in public participation or willingness to assume costs to improve the environment, although men are slightly more prone to accept them.

There are two classic studies based on the theory of gender socialization, which have grouped the most frequent interpretations of the gender gap and environmental concern: Davidson and Freudenburg (1996) and Blocker and Eckberg (1997). The first one point out that in the early stages of socialization (Gilligan 1982) women are assigned care, risk-avoiding, roles which are positively correlated with environmental concern. The second focuses on the social position of women in terms of employment status, homemaker status and parenthood also contribute to explaining their greater environmental concern vis-à-vis men, who are geared toward competition, market-focus, economic growth, exploitation of resources; that is to say, toward those values which are further away from environmentally friendly values. However, this second argument has found little empirical support to date (Strapko et al. 2016).

Recent studies have carried out a review of the role of gender in environmental sociology (Kennedy and Dzialo 2015) that allows for more complex interpretations of women's greater environmental concern. They propose to analyze the gender gap beyond the individual level and relate it to structural variables, concluding that women in countries with greater gender equality are also more pro-environmental than men (Dzialo 2017; Kennedy and Kmec 2018).

\section{Gender Gap in Political Knowledge}

Political knowledge has been defined as a general understanding of the political system and can be objectively opposed to subjective opinion (Althaus 2003). The literature divides political knowledge into three dimensions: knowledge of relevant political actors (i.e. political parties, trade unions), knowledge of the rules of the political system (i.e. how often elections are held, the government's powers) and knowledge of specific policies (i.e. current affairs, recent measures) (Althaus 2003; Delli Carpini and Keeter 2000).

There is empirical evidence that political knowledge and political participation are correlated (Deth and Elff 2004; Verba, Schlozman, and Brady 1995). Political participation means the ability of a person to get involved in actions that can influence the course of events, either through associations or acts of individual protest (Teorell, Torcal, and Montero 2007) Therefore, those who participate in politics the most also have the greatest ability to affect decision-making processes and to control political action (Scheufele et al. 2004; Verba, Schlozman, and Brady 1995). This is a crucial issue for the political development of democratic societies, and many studies have tried to discern the variables that affect political knowledge or what social groups can be 
regarded as more politically informed. The most consistent results suggest that political knowledge is greater among those with higher levels of education, more socioeconomic resources, and in particular, among men (Ferrín et al. 2020; Fraile 2014)

According to the gender socialization theory, men are preferentially socialized in the public sphere whereas women take charge of the domestic and private sphere, making political information, which belongs to the public sphere, more costly to women. In addition, the disadvantage of women in terms of employment, salary, studies, among others, detracts from their time and ability to obtain political information (Fraile 2014).

Recent studies have offered new interpretations about the gender gap in political knowledge taking into account, in addition to everything that has already been mentioned, the resulting bias when politics is measured by topics that men tend to be more interested in (political parties, policies about resource conflicts), while topics closer to daily life that women tend to be more interested in are excluded (local politics, governmental services and social programmes) (Delli Carpini and Keeter 2000; Ferrín et al. 2020).

Regarding the literature review, in this paper we refer specifically to political knowledge as knowledge of specific policies related to water management which can be objectively opposed to subjective opinion. From this point on, we present the following hypotheses:

$\mathrm{H1}$ : Women preference for domestic savings is related to greater environmental concern and less political knowledge.

In summary, according to the literature, environmental concern among women is related to individual behavior in the private sphere, which would explain their tendency to favor domestic efficiency over irrigation efficiency. However, domestic practices have less overall impact than irrigation measures on efficient water management. This issue would be less well known to women because belongs to the public sphere, more costly to women. The second hypothesis derives from the first:

$\mathrm{H} 2$ : if women had the same political knowledge as men, they would be less prone to prioritise domestic efficiency.

In order to test our hypotheses, we analyze gender differences concerning some aspects of environmental consciousness (environmental concern, self-reported level environmental information, trust in environmental groups, water-related environmental practices), as well as in one indicator of political knowledge on objective issues related to water policy (water allocation among productive sectors), the responder's opinion about regional water-management policies, and level of education. Second, we analyze what factors have a greater weight in this preference for domestic saving. Finally, we examine whether, when controlling for the variables that influence the choice of domestic savings, women continue to prefer domestic saving to a greater extent than men.

\section{Methodology}

\section{Data Analysis}

This study is based on the opinion survey on environmental attitudes Ecobarómetro de Andalucía (EBA) undertaken by the the Regional Ministry for the Environment and the 
Institute for Advanced Social Studies-Spanish National Research Council (IESA-CSIC). The survey was undertaken annually between 2004 and 2013 (except for 2012), and it is representative of Andalusian population according to a stratified random sampling. The final size of the sample is 19,627 people. The maximum expected error for the frequencies of each variable is $\pm 1.9 \%$, and $95 \%$ confidence level.

\section{Indicators}

The indicator used as a dependent variable, percentage of support for domestic savings, is based on responses to the following question: "Could you point out the most adequate way to improve water management in Andalusia?" Participants can choose between nine measures (Supplementary Appendix). Answers were divided into two categories: domestic savings and other measures. When the level of support for domestic saving is assessed, we must take into consideration the wide array of responses available.

The ten independent variables were divided into three blocks: environmental concern indicators, political knowledge indicator and socio-demographic indicators.

The environmental concern section includes indicators related to the different dimensions of environmental concern (Dunlap and Jones 2002): believes (environmental concern, trust in science, trust in environmental groups), cognitive (environmental information) and specific environmental issues (frequency of water-related environmental action).

To measure political knowledge, we use an objectively verifiable indicator, as Althaus proposes in their definition (2003) that concerns specific water-management policies: water allocation among productive sectors. Given that research on gender gap in political knowledge warns that a lower level of knowledge amongst women is sometimes due to the chosen topic of the questions (Ferrín et al. 2020; Fraile 2014), we have decided to include one question on the assessment of water management policies by the regional government. In this way, we can measure whether the topic sparks the same interest amongst men and women, that is, if they assess the topic in a similar way.

The third block concerns socio-demographic variables: sex, age, and educational level. These variables are related to environmental concerns (Dunlap and Jones 2002) and political knowledge (Fraile 2014).

\section{Statistical Analysis}

First, we undertook an exploratory descriptive analysis to assess changes in the level of support enjoyed by different water-management measures, paying special attention to men and women preferences concerning household and irrigation efficiencyrelated measures.

Second, we analyzed the gender gap in terms of environmental concern and political knowledge using Pearson's chi-squared test (bivariate analysis). Similarly, environmental concern and political knowledge indicator were subject to bivariate analysis to estimate their correlation with the household-savings indicator. 


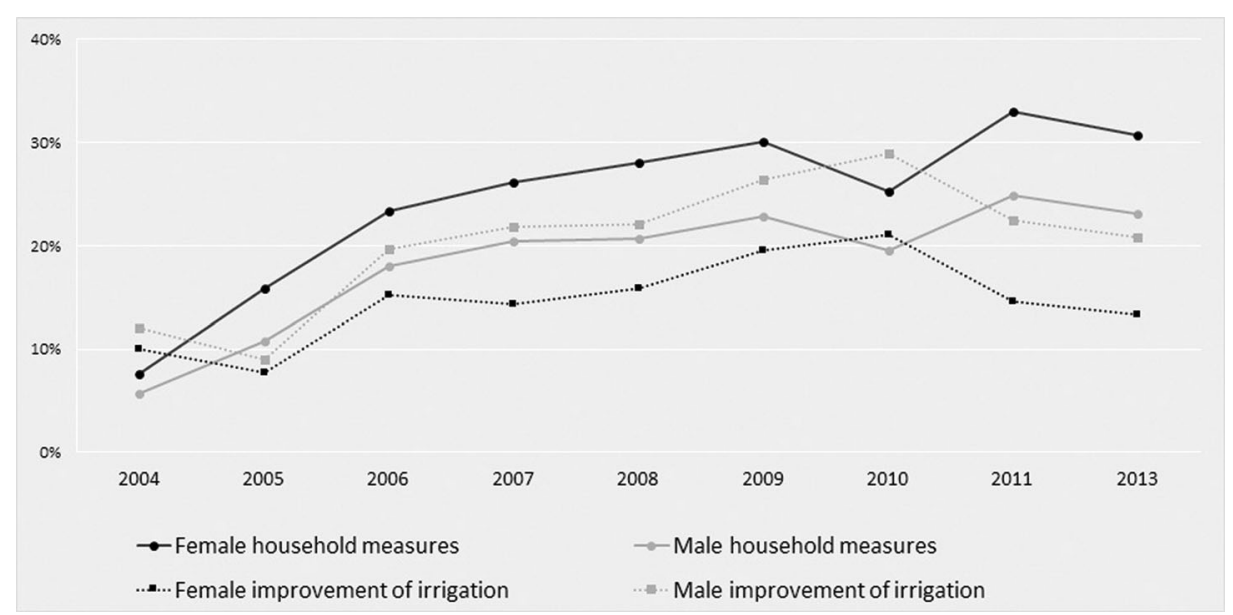

Figure 1. \% Support for increasing efficiency in irrigation and domestic water-saving, by sex. Source: Authors' own, based on Ecobarómetro de Andalucía (2004-2009).

Third, we conducted a logistic regression models using R language. Logistic regression allows us to modulate a categorical response, in our case the preference for household savings against other options, according to continuous or categorical predictor variables. It will allow us to establish what factors have a greater weight in the preference for household savings and to take gender into account.

\section{Results}

\section{Gender Gap in Level of Support for Efficient Water-Management Measures}

Figure 1 focuses on measures aimed at increasing household and agricultural efficiency. This increase in support for water-saving measures is in line with previous results of another survey-based research during periods of scarcity (Trumbo et al. 1999). In the case of Andalusia, it is worth mentioning the occurrence of the 2004-2008 drought episode, which was accompanied by a greater concern for the scarcity in the region and profound legislative reforms to update the drought protocols and to dictate exceptional measures to alleviate its effects (Paneque, Lafuente, and Vargas 2018). From 2006 onwards the percentage of participants who supported these measures increased, but, whereas men tend to look at irrigation, women tend to support household efficiency, which is in line with results obtained in developing countries (Cleaver 1998; Van Houweling 2016; Zwarteveen 1997). Recent studies in industrialized countries yield similar results and reveal that women are more prone to adopt water-efficient habits at the household level (Miller and Buys 2008; Ternes and Donovan 2020). However, this study is not concerned with individual behavior, but with public preferences on water management and the reasons behind women's tendency to support household efficiency over irrigation efficiency.

In 2004, men supported increasing irrigation efficiency over domestic efficiency (12\% vs. 5.8\%). From 2005 onwards, the level of support for both measures evens out (barely one or two points difference); however, in 2010, 29\% supported improving irrigation 
and $19.5 \%$ supported household efficiency. Women preferences are more regular: the difference in support for household efficiency over irrigation efficiency ranges from four points in 2004 to eighteen points in 2011.

To address the question at hand, henceforth we shall focus on the preferred option for women: water saving at the household level.

\section{Gender Gap in Environmental Concern and Political Knowledge}

Once the consistency of the annual evolution of men and women preferences has been attested, we shall consider the period 2004-2013 and the 19,627 interviews as a single unit of analysis.

During this period, $24.7 \%$ of women and $18.6 \%$ of men answered that domestic savings was the most efficient measure for improving water management in the region. To explain this statistically significant difference of opinion, which is our primary aim, we shall begin by testing the first hypothesis. First, we analyze the gender gap in terms of environmental concern and political knowledge, by detracting the values yielded by men and women in each of these indicators and estimate whether the difference is statistically significant (Table 1, column B). Second, we estimate whether the indicators used to assess the gender gap are related to preference for household savings by detracting the preference for household savings value from the aggregate values of the remaining preferences, establishing whether the difference is statistically significant (Table 1, column C).

It is observed that women exhibit a higher level of environmental concern than men, have less trust in science to solve environmental problems, claim a lower level of selfreported environmental information and claim to save water at the household level more often. However, no significant difference exists in terms of trust in environmental groups. These results are in line with previous results, except for this last variable, as women are generally held to have greater trust in environmental groups than men (Dzialo 2017; McCright and Xiao 2014; Miller and Buys 2008; Strapko et al. 2016; Zelezny, Chua, and Aldrich 2000). It is also observed that women are less knowledgeable concerning water allocation among sectors and are more likely not to express an opinion concerning water policies ("Does not answer" is significantly higher). In addition, the percentage of women with no education is higher. These results are in line with the existing literature (Ferrín et al. 2020; Fraile 2014).

Table 1 (column C) illustrates what features characterize participants who chose domestic saving over other measures. No significant differences exist in terms of environmental concerns, trust in science and daily water-saving habits, but they show less trust in environmental groups and present a lower degree of self-reported environmental information. The clearest difference between those who chose domestic saving and those who chose other measures is found in indicators related to political knowledge and assessment of water management policies: the former are less knowledgeable concerning how water is allocated among sectors and are less likely to answer questions about the government's performance, or to evaluate it positively. Finally, water saving is more likely to be chosen by younger participants and women, as well as being much less common among participants with university studies. The preference for domestic 
Table 1. Indicators according to sex and preferences for water-saving measures.

\begin{tabular}{|c|c|c|c|c|c|}
\hline Indicators & $\begin{array}{c}(\mathrm{A}) \\
\text { Total (\%) }\end{array}$ & $\begin{array}{c}\text { (B) } \\
M-W(\%)\end{array}$ & Sig & $\begin{array}{c}\text { (C) Water } \\
\text { savings-other } \\
\text { measures (\%) }\end{array}$ & Sig \\
\hline \multicolumn{6}{|l|}{ Environmental concern } \\
\hline Medium or low (0-7) & 64.3 & 3.5 & $* * *$ & -0.8 & \\
\hline High (8-10) & 35.7 & -3.5 & $* * *$ & 0.8 & \\
\hline \multicolumn{6}{|l|}{ Trust in science } \\
\hline No $(1-3)$ & 62.2 & -3.7 & $* * *$ & -0.1 & \\
\hline Yes $(4-5)$ & 37.8 & 3.7 & $* * *$ & 0.1 & \\
\hline \multicolumn{6}{|l|}{ Trust in environmental groups } \\
\hline No $(1-3)$ & 56.1 & -0.3 & & 2.2 & $* * *$ \\
\hline Yes $(4-5)$ & 43.9 & 0.3 & & -2.2 & $* * *$ \\
\hline \multicolumn{6}{|l|}{ Individual actions (water saving) } \\
\hline Not always (1-3) & 18.1 & 5.2 & $* * *$ & 0.4 & \\
\hline Always (4) & 81.9 & -5.2 & $* * *$ & -0.4 & \\
\hline \multicolumn{6}{|c|}{ Self-reported environmental information } \\
\hline Low $(1-3)$ & 75.2 & -6.1 & $* * *$ & 3.4 & $* * *$ \\
\hline High (4-5) & 24.8 & 6.1 & $* * *$ & -3.4 & $* * *$ \\
\hline \multicolumn{6}{|l|}{ Knowledge of water allocation } \\
\hline Does not know (3-4) & 53.2 & -8.3 & $* * *$ & 18.0 & $* * *$ \\
\hline Knows $(1-2)$ & 46.8 & 8.3 & $* * *$ & -18.0 & $* * *$ \\
\hline \multicolumn{6}{|c|}{ Assessment of Regional government's water-management policies } \\
\hline Negative $(1-3)$ & 42.7 & 6.8 & $* * *$ & -7.3 & $* * *$ \\
\hline Positive $(4-5)$ & 32.1 & 4.7 & $* * *$ & 4.4 & $* * *$ \\
\hline Does not know/does not answer & 25.2 & -11.5 & $* * *$ & 2.9 & $* * *$ \\
\hline \multicolumn{6}{|l|}{ Educational level } \\
\hline No studies & 32.9 & -7.0 & $* * *$ & 1.4 & \\
\hline Primary education & 33.5 & 3.2 & $* * *$ & -0.4 & \\
\hline Secondary education & 19.0 & 3.1 & $* * *$ & 0.6 & \\
\hline University education & 14.5 & 0.6 & & -1.6 & $* * *$ \\
\hline \multicolumn{6}{|l|}{ Age } \\
\hline$<30$ years & 21.5 & 2.0 & $* * *$ & 4.6 & $* * *$ \\
\hline $30-44$ years & 31.1 & 2.6 & $* * *$ & -1.2 & \\
\hline $45-59$ years & 23.1 & 0.6 & & -3.3 & $* * *$ \\
\hline 60 years and over & 24.4 & -5.2 & $* * *$ & 0.0 & \\
\hline \multicolumn{6}{|l|}{ Sex } \\
\hline Female & 51.1 & & & 8.9 & $* * *$ \\
\hline Male & 48.9 & & & -8.9 & $* * *$ \\
\hline
\end{tabular}

Source: Authors' own, after Ecobarómetro de Andalucía. Note: Asterisks indicate significant differences, in percentage, between the values yielded by men and women in each indicator (Column B) and between those who chose domestic saving and other measures (Column C). ${ }^{* * *} p<0.001$.

savings is more related to political knowledge and socio-demographic blocks than environmental concern block.

\section{Logistic Regression: Explicative Variables for the Choice of Domestic Savings}

The results analyzed in the previous section are used to select the independent variables for the logistic regression model: those that present a statistically significant relation to the dependent variable (domestic savings) and the variable sex. These are self- reported levels of environmental information, knowledge about water-allocation policies, opinion about regional government's water-management policies, educational level, and age. The interaction of all these variables with the variable sex is also calculated.

The methodology used is a stepwise logistic regression in which, through conditional likelihood contrasts (likelihood ratio test), different models and variables are compared 
Table 2. Analysis of deviance in response/relation to domestic savings.

\begin{tabular}{lcccc}
\hline & DF & $X^{2}$ & $\operatorname{Pr}(>$ Chisq) & Signif \\
\hline Sex & 1 & 66.2058 & $4.062 \mathrm{e}-16$ & $* * *$ \\
Age & 3 & 35.2501 & $1.079 \mathrm{e}-07$ & $* * *$ \\
Educational level & 3 & 5.2047 & 0.157409 & $* *$ \\
Self-reported environmental information & 1 & 8.0648 & 0.004513 & $* * *$ \\
Knowledge of water allocation & 1 & 339.7393 & $<2.2 \mathrm{e}-16$ & $* *$ \\
Assessment of regional government's water-management policies & 2 & 38.5664 & $4.221 \mathrm{e}-09$ & \\
Age * Sex & 3 & 3.6032 & 0.307621 & \\
Educational level *Sex & 3 & 1.3278 & 0.722532 & \\
Self-reported environmental information *Sex & 1 & 0.7356 & 0.391074 \\
Knowledge of water allocation * Sex & 1 & 0.880 & 0.348076 \\
Assessment of Regional government's water-management & 2 & 4.1320 & 0.126693 & \\
$\quad$ policies *Sex & & & & \\
\hline
\end{tabular}

Note: Asterisks indicate statistically significant variable to fit model ${ }^{* * *} p<0.001 ;{ }^{* *} p<0.01 ;{ }^{*} p<0.5$.

Table 3. Coefficients.

\begin{tabular}{lccccc}
\hline & Estimate & Std error & $T$ value & $\operatorname{Pr}(>\mathrm{It})$ & Signif \\
\hline (Intercept) & -0.60443 & 0.06316 & -9.570 & $<2 \mathrm{e}-16$ & $* * *$ \\
Male & -0.30402 & 0.04515 & -2.861 & 0.004225 & $* *$ \\
$30-44$ years & -0.19333 & 0.04984 & -3.879 & 0.000105 & $* * *$ \\
45-69 years & -0.29776 & 0.05549 & -5.366 & $8.15 \mathrm{e}-08$ & $* * *$ \\
60 years and over & -0.26897 & 0.05847 & -4.600 & $4.24 \mathrm{e}-06$ & $* * *$ \\
Primary education & -0.08096 & 0.04989 & -1.623 & 0.104461 & \\
Secondary education & -0.06016 & 0.05851 & -1.028 & 0.303830 & $*$ \\
University education & -0.15188 & 0.06539 & -2.323 & 0.020201 & $* *$ \\
High level of self- reported environmental information & -0.12920 & 0.04515 & -2.861 & 0.004225 & $* * *$ \\
Knowledge of water allocation & -0.70589 & 0.03834 & -18.411 & $<2 \mathrm{e}-16$ & $* * * 16$ \\
Positive assessment of regional government's & -0.26713 & 0.04349 & 6.142 & $8.29 \mathrm{e}-10$ & $* * *$ \\
$\quad$ water-management policies & & & & & \\
No opinion on regional government's & -0.16069 & 0.04698 & 3.420 & 0.000627 & $* * *$ \\
$\quad$ water-management policies & & & & & \\
\hline
\end{tabular}

Note: Asterisks indicate statistically significant regression coefficient ${ }^{* * *} p<0.001 ;{ }^{* *} p<0.01 ;{ }^{*} p<0.5$.

to reach the most parsimonious model (Table 2). The variable that better explains the preference for domestic savings is knowledge of water allocation, followed by sex. Assessment about governmental action and age carry a similar weight whereas selfreported level of environmental information and level of education play little role in the choice. Finally, the interaction between the various variables and sex is not significant, as independent variables behave similarly for men and women.

Afterwards, we make a new fit model without taking into consideration the variable sex to get correct estimations of remaining variables. Table 3 includes the coefficients that allow us to estimate the likelihood that domestic savings will be chosen by each of the groups formed according to the independent variables: domestic savings is less prevalent among men, people aged 30 or over, those with a higher degree of selfreported environmental information, those who know how water is allocated and those with university studies.

The marginal effects (Figure 2) allow us to graphically respond to questions such as: is domestic savings preference more likely among women once the effect of the other variables in the model is controlled? In this case, the answer is yes. Also, we found that preference for domestic savings is more likely among those who do not know how water is allocated. Similarly, those with a positive opinion of governmental measures are more likely to choose domestic savings. It is more difficult to assess the preferences of 

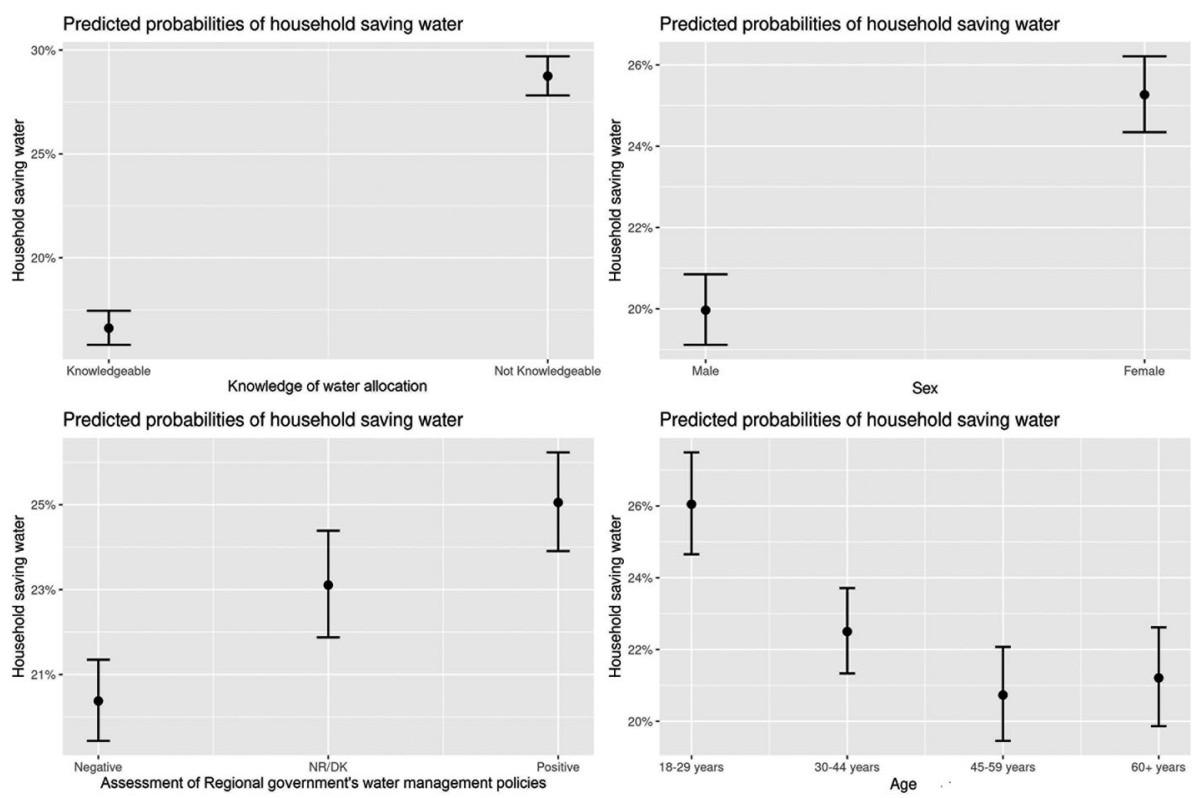

Figure 2. Marginal effects plots of model for predicting the likelihood of domestic savings. Source: Authors' own, based on Ecobarómetro de Andalucía (2004-2013).

those who have no opinion. Finally, participants under 30 years of age are more prone to choosing domestic savings.

In summary, the data indicates that women preference for domestic savings is 1.31 times higher $(31 \%)$. The logistic regression model does not fully explain women preferences for domestic savings. Controlling the effect of the indicators (water allocation, assessment about water-management policies, self-reported level of environmental information, educational level, age), women preference for this choice is still 1.23 times higher. From a statistical perspective, these are modest results, but they have important implications: differences among men and women are only partially caused by the level of knowledge about water issues.

\section{Effect of Political Knowledge, Environmental Information and Educational Level among Men and Women in Terms of Domestic Savings Preferences}

The graphic representation of the marginal effects plots illustrates that, even if interactions with the variable sex are dismissed, the estimated probabilities that domestic savings will be chosen are different among men and women when the effect of political knowledge (water allocation) and self-reported level of environmental information are controlled; that is, the "effect size" is not the same for men and women.

Participants with accurate knowledge about water allocation policies are less likely to choose domestic savings regardless of sex (for this reason, the interaction of these two variables is not significant for the model, see Figure 3). However, should all participants have accurate knowledge about this issue, the women preference for domestic savings would still be 1.28 times higher (based on the coefficients 


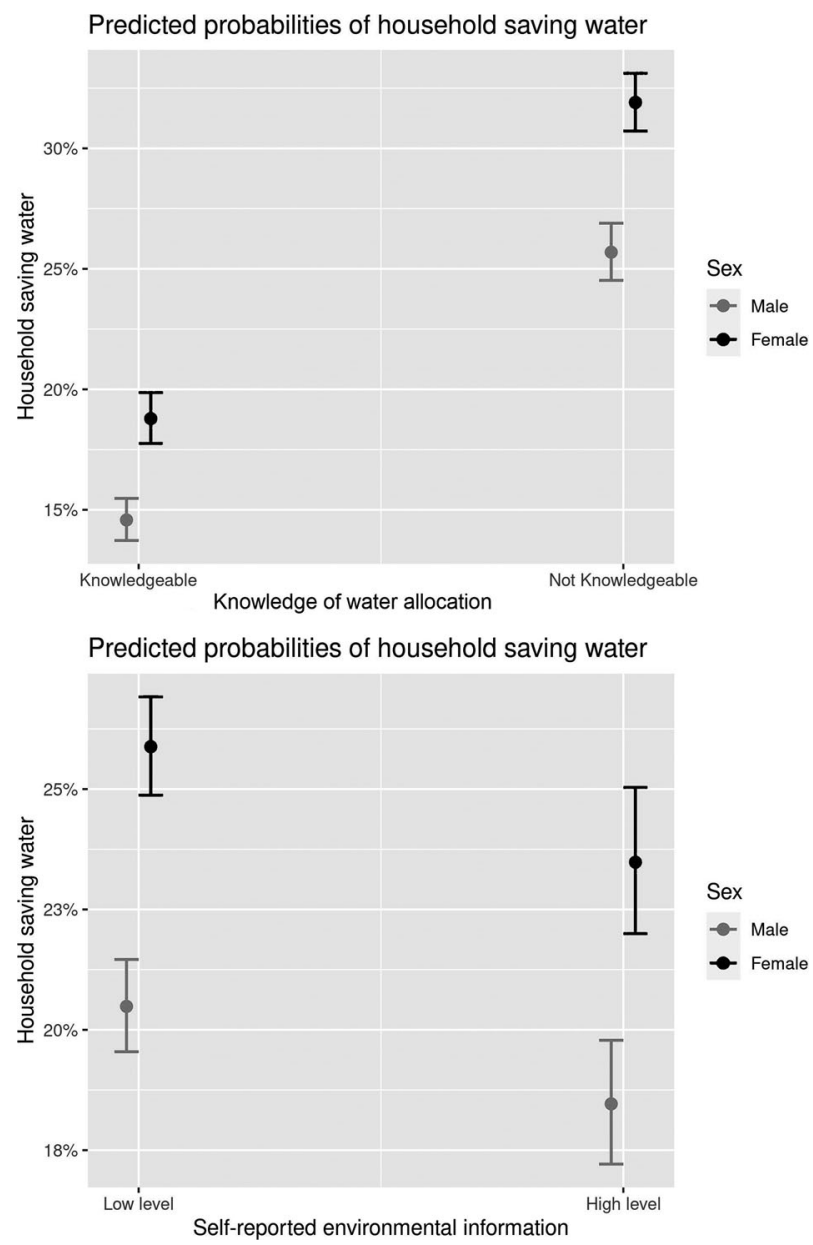

Figure 3. Marginal effects plots of model for predicting the likelihood of domestic savings by sex. Source: Authors' own, based on Ecobarómetro de Andalucía (2004-2013).

in Table 3). An increase in self-reported level of environmental information decreases the probability of choosing domestic savings, but the effect is not statistically significant.

Thus far, we have reached the conclusion that knowledge of water allocation is the most influential factor concerning water-management preferences. We also know that more men than women have accurate knowledge of this, and that this partially explains why more women than men chose domestic savings. If this is the case however, how can we explain why more men than women know how water is allocated? According to the literature, men possess more political knowledge because they have more socio-economics resources such as educational level (Fraile 2014). Indeed, in the sample the educational level of women is lower than that of men (Table 1). We must establish whether educational level has the same impact on men and women in terms of knowledge about water allocation, this being a critical issue for water management.

The analysis of marginal effects suggests that knowledge about water allocation is higher among people with university studies, regardless of sex (Figure 4). However, if we keep the 


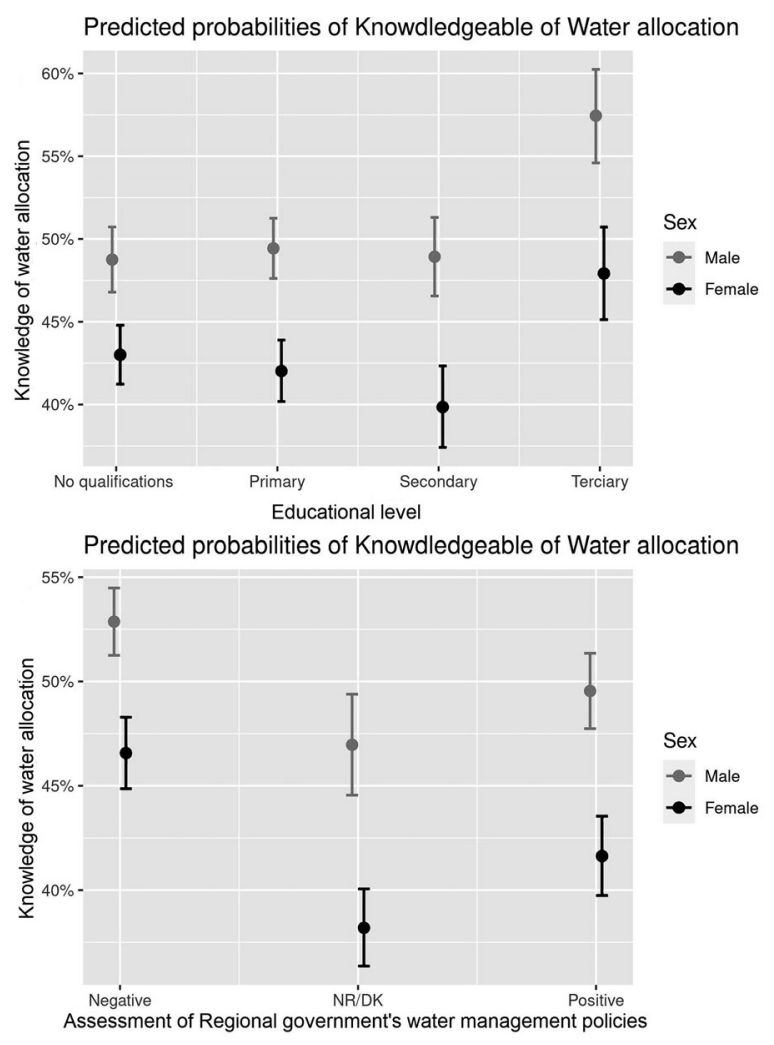

Figure 4. Marginal effects plots of model for predicting the knowledge water allocation by sex. Source: Authors' own, based on Ecobarómetro de Andalucía (2004-2013).

remaining variables at their average value (self-reported level of environmental information, opinion about water governance and age) the percentage of women with university education who have accurate knowledge about water allocation is lower than that of men with same education level.

Lastly, we would also like to know whether knowledge on water topics is related to the assessment of water policies. In both genders, the most critical with the government are those respondents who are the most knowledgeable about water distribution. On the contrary, those who have no opinion on the government's actions have less knowledge, and this is more pronounced amongst women. In short, women show less assessments on public water policies, which results in less knowledge about water allocation and a greater imprecision when establishing their own preferences on how water management should be improved in Andalusia (Figure 2).

\section{Discussion}

These results compel us to revise the hypothesis concerning women preferences: "women preference for domestic savings is related to greater environmental concern and lesser political knowledge". Environmental concern indicators are higher (except 
regarding self-reported environmental information) and political knowledge is lower. Furthermore, men are more critical about the government's water management policies, while women tend to be more obliging or avoid giving an assessment (Table 1). These results confirm the most stable studies on gender gaps in environmental concern (McCright and Xiao 2014; Zelezny, Chua, and Aldrich 2000) and political knowledge and interest about certain topics (Ferrín et al. 2020; Fraile 2014). However, these factors do not affect in the same way women's preferences on what measures should be adopted to improve water management in Andalusia.

Environmental concern, as measured in this research, is not significantly correlated with water-management preferences, and not even those participants who claim to save water in their domestic chores project these attitudes onto their preferences, by prioritizing domestic savings. In contrast, political knowledge is strongly related to watermanagement preferences, that is, with the public sphere (Fraile 2014). For participants with more knowledge, or educational level, domestic saving is not the most important management measure to solve water problems (Table 1) in a context such as the Andalusian, with a serious situation of water stress mainly related to agricultural consumption. As such, and this is a key finding in this research, if women are more inclined to domestic savings it is not because they present higher levels of environmental concern: rather, it is the aggregate effect of poor knowledge about water-allocation policies, less self-reported level of environmental information and lower educational levels (Figure 3).

These results emphasize the need to close the gender gap in terms of political knowledge in order to incorporate women opinion into water-management decision-making processes and enroll their support for efficient policies (for instance, increasing the efficiency of irrigation in the Andalusian context without downplaying any other effort for making an efficient use of water with less impact). However, in the model that considers the variable sex, results indicate that, when women have accurate knowledge of water-allocation policies, their preference for domestic savings decreases although not to the same degree as among men (Figure 3). The results reject, at least partially, the second hypothesis that, "if women had the same political knowledge as men, they would be less prone to prioritize domestic efficiency". In addition, bringing education to a level does not have a parallel effect on political knowledge (Figure 4). Therefore, and as Fraile (2014) points out, educational level may have different effects on the political knowledge of men and women, and gender issues should be analyzed with a broader approach that allows us to integrate more factors that do not only have to do with individual variables such as educational level (Dzialo 2017; Kennedy and Kmec 2018).

The model has identified the aggregate effect of knowledge about water allocation, educational level, and self-reported level of environmental information, but has not fully explained the women tendency to choose domestic savings to improve water management in the region. This can be interpreted in several ways. First, we must insist on closing the gender gap in terms of political knowledge to incorporate women into decision-making processes because this has been found to affect water-management preferences (Table 1). We have also found that, according to Fraile (2014), the percentage of women with no opinion on governmental policies is significantly higher than that of men, and that does not allow to know their priorities on water management (Table 1, 
Figure 2). Moreover, those who do not have an opinion on the government's actions have worse knowledge on water distribution (Figure 4). Water management is further from women's interests in both ways.

Second, this study's methodological limitations do not allow us to ascertain what kind of political information, other than that related to water-allocation policies, could contribute to closing the gender gap. The Ecobarómetro survey was designed to measure environmental concern, and it lacks the variables to fully meet more dimensions of the political knowledge that has been found to be so relevant. It has been demonstrated that the educational gender gap scarcely explains the gender gap in water-related knowledge (Figure 4). If educational level is a low predictor of knowledge about water issues for women, we will have to look for other factors more related to women's roles (Gilligan 1982) or the social position they occupy (Dzialo 2017) so that the agrarian issue and its water consumption is not so far away from their political interests. According to Ferrín et al. (2020) women show high levels of political knowledge in those areas related to their social roles, such as health, education, food, etc.

Third, even women who know that agriculture is the sector that consumes the most water are more likely than men to choose domestic savings as a management measure (Figure 3). The differences in roles and social position, which bring men closer to the productive sector, including agriculture, and women closer to the domestic sphere, seem to share weight with political knowledge when it comes to offering solutions to the water problem. Therefore, the main value for understanding that increasing political knowledge among women is not tantamount to bringing their opinion onto a level with that of men, but rather to increasing their ability to affect political decision making (Deth and Elff 2004; Verba, Schlozman, and Brady 1995) -i.e. to incorporating the gender perspective into water management and improving governance.

\section{Conclusion}

This study confirms the need to investigate women preferences about water management in industrialized countries. Most of the literature on gender-sensitive water governance still focuses on developing countries and on how to incorporate the opinions of women as productive factors, and not only as domestic factors, into decision-making. This study demonstrates that many women in a European region (Andalusia) also continue thinking about water management from a domestic perspective. This is concerning in two ways. First, insofar as it directly affects hydrological planning. In Andalusia, which faces a severe risk of hydrological stress in direct relation to the intensification of drought owing to climate change, and in which agriculture accounts for $80 \%$ of all water available, domestic savings have less of an effect than increasing the efficiency of irrigation systems. Therefore, the fact that women are more likely to choose saving water in the domestic sphere means that they may be left out of water governance and the solutions to water scarcity. Secondly, as pointed out by the critical trend in environmental sociology, if we settle for indulgent interpretations of women's greater environmental concern in their domestic behavior, including water saving, we will be making the same mistake as in non-industrialized countries that have failed to incorporate women into formal governance structures without taking into account the roles and positions they occupy in their 
communities. Andalusian women save more water at home, but according to our research, this does not explain why they consider domestic savings to be the best management measure. To understand women's preferences in the public sphere, we must look for broader patterns of gender inequality, in the roles they play and the position they occupy in their social context. We know that political knowledge is important in the formation of water management preferences, but that this knowledge is achieved not only by educational level, but by interest in specific public issues, and water management should be one of them. Further research is needed to ascertain what factors affect women's preferences in water management as a step toward gender perspective in water governance. More complete explanations will come from the connection of various disciplines as we have shown with this research combining contributions from classical environmental sociology, feminist political ecology, political sociology and human geography.

\section{Acknowledgements}

We wish to thank the Instituto de Estudios Sociales de Andalucía del Consejo Superior de Investigaciones Científicas (IESA-CSIC) for the cession of the Ecobarómetro de Andalucía.

\section{Funding}

This work was supported by the Fundación Española para la Ciencia y la Tecnología (FECYT). Call 2019 - [Grant "Observatorio Ciudadano de la Sequía" (FCT-19-14568)].

\section{ORCID}

Regina Lafuente (D) http://orcid.org/0000-0002-2623-9373

Pilar Paneque (D) http://orcid.org/0000-0003-0652-1520

\section{References}

Akhmouch, A., and D. Clavreul. 2016. Stakeholder engagement for inclusive water governance: Practicing what we preach. Water 8 (5):204. doi:10.3390/w8050204.

Althaus, S. 2003. Collective preferences in democratic politics: Opinion surveys and the will of the people. Cambridge: Cambridge University Press.

Arora-Jonsson, S. 2011. Virtue and vulnerability: Discourses on women, gender and climate change. Global Environmental Change 21 (2):744-51. doi:10.1016/j.gloenvcha.2011.01.005.

Arora-Jonsson, S. 2014. Forty years of gender research and environmental policy: Where do we stand? Women's Studies International Forum 47:295-308. doi:10.1016/j.wsif.2014.02.009.

Blocker, T. J., and D. L. Eckberg. 1997. Gender and environmentalism: Results from the 1993 general social survey. Social Science Quarterly 78 (4):586-93.

Calás, M., L. Smircich, E. Holvino, et al. 2014. Theorizing gender-and-organization: Changing times changing theories? In The Oxford handbook of gender in organizations, ed. S. Kumra., 605-59. London: Oxford University Press.

Centro de Estudios y Experimentación de Obras Públicas (CEDEX). 2017a. Evaluación del Impacto del Cambio Climático en los Recursos Hídricos y Sequías en España [Assessment of the impact of climate change on water resources and droughts in Spain]. Madrid: Dirección General del Agua, Secretaría de Estado de Medio Ambiente. 
Centro de Estudios y Experimentación de Obras Públicas (CEDEX). 2017b. Síntesis de los Planes Hidrológicos Españoles. Segundo Ciclo de la Directiva Marco del Agua (2015-2021) [Synthesis of the Spanish hydrological plans. second cycle of the water framework directive (2015-2021)]. Madrid: Dirección General del Agua, Secretaría de Estado de Medio Ambiente.

Chafetz, J. S. 2006. The varieties of gender theory in sociology. In Handbook of the sociology of gender, ed. J. S. Chafetz, 3-23. New York: Springer

Cleaver, F. 1998. Choice, complexity and change: Gendered livelihoods and the management of water. Agriculture and Human Values 15 (4):293-9. doi:10.1023/A:1007511816437.

Cleaver, F., and K. Hamada. 2010. Good“" water governance and gender equity: a troubled relationship. Gender \& Development 18 (1):27-41. doi:10.1080/13552071003599996.

Davidson, D. J., and W. R. Freudenburg. 1996. Gender and environmental risk concerns: A review and analysis of available research. Environment and Behavior 28 (3):302-39. doi:10. $1177 / 0013916596283003$.

Del Moral, L., P. van der Werff, K. Bakker, and J. Handmer. 2003. Global trends and water policy in Spain. Water International 28 (3):358-66. doi:10.1080/02508060308691710.

Delli Carpini, M., and S. Keeter. 2000. Gender and political knowledge. In Gender and American politics: Women, men, and the political process, eds. S. T. Rinehart, and J. Josephson, 23-50. Armonk: M.E. Sharpe.

Deth, J. W., and M. Elff. 2004. Politicisation, economic development and political interest in Europe. European Journal of Political Research 43 (3):477-508. doi:10.1111/j.1475-6765.2004. 00162.x.

Dunlap, R., and R. Jones. 2002. Environmental Concern: Conceptual and Measurement Issues. In Handbook of Environmental Sociology, eds. R. Dunlap and W. Michelson, 482-524. London: Greenwood Press.

Dzialo, L. 2017. The feminization of environmental responsibility: A quantitative, cross-national analysis. Environmental Sociology 3 (4):427-37. doi:10.1080/23251042.2017.1327924.

EEA. 2017. Climate change, impacts and vulnerability in Europe 2016. An indicator-based report. Report No 1/2017. Luxemburg: Publications Office of the European Union.

Ferrín, M., M. Fraile, G. M. García-Albacete, and R. Gómez. 2020. The gender gap in political interest revisited. International Political Science Review 41 (4):473-89. doi:10.1177/ 0192512119860260.

Figueiredo, P., and P. E. Perkins. 2013. Women and water management in times of climate change: Participatory and inclusive processes. Journal of Cleaner Production 60:188-94. doi:10. 1016/j.jclepro.2012.02.025.

Fraile, M. 2014. Do women know less about politics than men? The gender gap in political knowledge in Europe. Social Politics 21 (2):261-89. doi:10.1093/sp/jxu006.

Gilligan, C. 1982. In a different voice. Cambridge, MA: Harvard University Press.

Instituto de Estadística y Cartografía de Andalucía (IECA). 2020. Anuario Estadístico de Andalucía. [Statistical Yearbook of Andalusia] http://www.juntadeandalucia.es/institutodeestadisticaycartografia/anuario/index.htm (accessed January 20, 2021)

Instituto Nacional de Estadística (INE). 2020. Atlas de distribución de renta de los hogares $(A D R H)$ [Atlas of household income distribution]. Madrid: Subdirección General de Estadísticas Sociodemográfica.

IPCC. 2014. Summary for policymakers. In Climate change 2014: Impacts, adaptation, and vulnerability. Part A: Global and sectoral aspects. Contribution of working group II to the fifth assessment report of the IPCC, eds. C.B . Field. Cambridge: Cambridge University Press.

IUCN. 2018. Women as change-makers in the governance of shared waters. https://www.womenforwater.org/uploads/7/7/5/1/77516286/iucn_women_changemakers_final_web.pdf (accessed March 15, 2020)

Kennedy, E. H., and J. Kmec. 2018. Reinterpreting the gender gap in household pro-environmental behaviour. Environmental Sociology 4 (3):299-310. doi:10.1080/23251042.2018.1436891.

Kennedy, E. H., and L. Dzialo. 2015. Locating gender in environmental sociology. Sociology Compass 9 (10):920-9. doi:10.1111/soc4.12303. 
Lafuente, R., and E. Moyano. 2011. Andalucía y el Medio Ambiente 2000-2010: 10 Años del Ecobarómetro [Andalucía and the environment 2000-2010: 10 Years of the ecobarometer] Seville: Junta de Andalucía.

McCright, A. M., and C. Xiao. 2014. Gender and environmental concern: Insights from recent work and for future research. Society \& Natural Resources 27 (10):1109-13. doi:10.1080/ 08941920.2014 .918235 .

MacGregor, S. 2009. A stranger silence still: The need for feminist social research on climate change. The Sociological Review 57 (2_suppl):124-40. doi:10.1111/j.1467-954X.2010.01889.x.

Miller, E., and L. Buys. 2008. Water-recycling in South-East Queensland, Australia: What do men and women think? Rural Society Journal 18 (3):220-9. doi:10.5172/rsj.351.18.3.220.

Ministerio de Agricultura, Pesca y Alimentación (MAPAMA). 2020. Encuesta sobre Superficies y Rendimientos de Cultivos (ESYRCE). [Crop surface and yield survey] https://www.mapa.gob.es/ es/estadistica/temas/estadisticas-agrarias/andalucia_2020_tcm30-553612.pdf (accessed January 21, 2021)

Ministerio para la Transición Ecológica y el Reto demográfico (MITECO). 2020. http://www. chguadalquivir.es/la-gestion-del-agua\#Infraestructurashidraulicas (accessed January 29, 2021).

Nagel, J. 2015. Gender and climate change: Impacts, science, policy. New York, Routledge.

OECD. 2015a. Principles on water governance. http://www.oecd.org/governance/oecd-principleson-water-governance.htm (accessed September 12, 2020).

OECD. 2015b. Stakeholder engagement for inclusive water governance. doi:10.1787/ 9789264231122-en. (accessed September 15, 2020).

OECD. 2018. Implementing the OECD principles on water governance: Indicator framework and evolving practices. doi:10.1787/9789264292659-en (accessed August 15, 2020).

Paneque, P. 2015. Drought management strategies in Spain. Water 7 (12):6689-701. doi:10.3390/ w7126655.

Paneque, P., R. Lafuente, and J. Vargas. 2018. Public attitudes toward water management measures and drought: A study in southern Spain. Water 10 (4):369. doi:10.3390/w10040369.

Pearse, R. 2017. Gender and climate change. WIREs Climate Change 8 (2):451. doi:10.1002/wcc. 451.

Sampedro, D., and L. del Moral. 2014. Tres décadas de política de aguas en Andalucía. Análisis de procesos y perspectiva territorial [Three decades of water policy in Andalusia. Process analysis and territorial perspective]. Cuadernos Geográficos 53 (1):36-67.

Sánchez-Plaza, A., P. Broekman, and P. Paneque. 2019. Analytical framework to assess the incorporation of climate change adaptation in water management: Application to the Tordera River basin adaptation plan. Sustainability 11 (3):762. doi:10.3390/su11030762.

Scheufele, D. A., M. C. Nisbet, D. Brossard, and E. C. Nisbet. 2004. Social structure and citizenship: Examining the impacts of social setting, network heterogeneity, and informational variables on political participation. Political Communication 21 (3):315-38. doi:10.1080/ 10584600490481389.

Strapko, N., L. Hempel, K. MacIlroy, and K. Smith. 2016. Gender differences in environmental concern: Reevaluating gender socialization. Society \& Natural Resources 29 (9):1015-31. doi:10. 1080/08941920.2016.1138563.

Swyngedouw, E. 2015. Liquid power: Contested hydro-modernities in twentieth-century Spain. Cambridge: MIT Press.

Teorell, J., M. Torcal, and J. R. Montero. 2007. Political participation: mapping the terrain. In Citizenship and involvement in European democracies, eds J. van Deth, J. R. Montero, and A. Westholm, 334-57. London: Routledge.

Ternes, B., and B. Donovan. 2020. Hydrologic habitus: Wells, watering practices, and water supply infrastructure. Nature and Culture 15 (1):32-53. doi:10.3167/nc.2020.150103.

Tirado, D. A., A. Díez-Minguela, and A. Martínez-Galarraga. 2016. Regional inequality and economic development in Spain, 1860-2010. Journal of Historical Geography 54:87-98. doi:10. 1016/j.jhg.2016.09.005. 
Trumbo, C. W., N. L. Markee, G. J. O’Keefe, and E. Park. 1999. Antecedent precipitation as a methodological concern in attitude surveys on water conservation. Water Resources Research 35 (4):1269-73. doi:10.1029/1998WR900123.

UNESCO. 2015. Water for women: Every woman counts. Every second counts. World Water Assessment Programme. https://www.worldwaterweek.org/event/4714-women-for-water-everywoman-counts-every-second-counts (accessed September 7, 2020).

Van Houweling, E. 2016. A good wife brings her husband bath water: Gender roles and water practices in Nampula. Society \& Natural Resources 29 (9):1065-78. doi:10.1080/08941920.2015. 1095377.

Verba, S., K. L. Schlozman, and H. E. Brady. 1995. Voice and equality: Civic volunteerism in American politics. Cambridge: Harvard University Press.

Villarín, M. 2019. Methodology based on fine spatial scale and preliminary clustering to improve multivariate linear regression analysis of domestic water consumption. Applied Geography 103: 22-39. doi:10.1016/j.apgeog.2018.12.005.

World Bank (WB). 2019. Women in water utilities: Breaking barriers. https://openknowledge. worldbank.org/handle/10986/32319 License: CC BY 3.0 IG (accessed September 16, 2020).

Zelezny, L. C., P. P. Chua, and C. Aldrich. 2000. Elaborating on gender differences in environmentalism. Journal of Social Issues 56 (3):443-57. doi:10.1111/0022-4537.00177.

Zwarteveen, M. 1997. Water: From basic need to commodity: A discussion on gender and water rights in the context of irrigation. World Development 25 (8):1335-49. doi:10.1016/S0305$750 \mathrm{X}(97) 00032-6$. 